\title{
BREEDING OF THE CHILEAN OYSTER (OSTREA CHILENSIS PHILIPPI) IN THE LABORATORY
}

\author{
By P. R. WALNE \\ Ministry of Agriculture, Fisheries and Food, Mussel Purification Tanks, \\ Conway
}

$\mathrm{T}$ HE 1948 Lund University Expedition to Chile collected samples of Ostrea chilensis from the northern part of the Golfo de Ancud and in the neighbouring Bahia de Ancud, where they were found on stony beaches and on sand and mud down to depths of $11 \mathrm{~m}$. In one of the samples collected in Novomber 1948, sevoral specimens brooding eggs and larvæ were found which were stated to measure $0.5-0.75 \mathrm{~mm}$ and $0.7-1.2 \mathrm{~mm}$ respectively. This is abnormally large for Ostrea eggs and larvæ and suggested that all the larval development would occur while being brooded in the mantle cavity and that the duration of the planktonic stage would be very short. A similarly reduced planktonic stage has been recently reported for the New Zealand oyster, O. lutaria ${ }^{2}$.

A consignment of $O$. chilensis was received in good condition in this laboratory on September 17, 1962, and placed in glass tanks with running sea-water. Within a few hours a number of early embryos were aborted. indicating that some of the oysters were brooding when they arrived. Four liberations of larvæ were obtained in October during which period the temperature of the water gradually decreased from $15^{\circ}$ to $11^{\circ} \mathrm{C}$. This range is approximately that found in the late spring and early summer on their natural grounds ${ }^{3}$. Thirteen liberations occurred in November when the temperature was being maintained at $11^{\circ}-14^{\circ} \mathrm{C}$.

The larve at liberation had a well-developed foot and eyespot, and mostly metamorphosed within a few hours on the glass and slate sides of the tank and on mussel shells suspended for spat collection in the tank. The shell shape agreed with that figured by Ranson ${ }^{4}$ although the size was less than that estimated by Soot-Ryen ${ }^{x}$. The mean and range of shell-length of six liberations are given in Table 1.

$\begin{array}{ccc} & \text { Table } 1 & \\ & \text { Mean } & \text { Range } \\ 1 & 435 \mu & 390-510 \mu \\ 2 & 477 \mu & 430-500 \mu \\ 3 & 475 \mu & 450-490 \mu \\ 4 & 490 \mu & 460-510 \mu \\ 4 & 492 \mu & 450-520 \mu \\ 5 & 491 \mu & 460-510 \mu \\ 6 & 450-51 \mu\end{array}$

The larva were sufficiently active to swim up to the surface film, although the velum is small compared with that of 0 . edulis. The gill rudiment, consisting of 6-8 projections on the left side, is more pronounced than in the mature larva of $O$. edulis. Some larvæ isolated in a glass beaker had not become attached $24 \mathrm{~h}$ later, suggesting that clean glass was not a favourable surface, although two specimens had metamorphosed without attaching--a phenomenon which has also been seen in O. edulis. Some of the larva which had not metamorphosed were placed on mussel shell and two became attached in the next $5 \mathrm{~h}$, indicating that metamorphosis ean be delayed for at least $24 \mathrm{~h}$.

Two brooding adults have been opened and the number of eggs or embryos estimated (broods of $O$. edulis of this

\begin{tabular}{|c|c|c|c|}
\hline \multicolumn{4}{|c|}{ Table 2} \\
\hline Hcan diam. & Internal vol. & Dry meat wt. & No, of embryos \\
\hline $.51 \mathrm{~mm}$ & $11.5 \mathrm{ml}$. & $0.94 \mathrm{~g}$ & 62,800 \\
\hline
\end{tabular}

size would contain about 500,000 embryos) (Table 2). Early embryos are white in colour, but at the later stages the brood is light brown in colour instead of the grey or black of $O$. edulis.

One adult was observed to be spilling a fow eggs in the exhalent current. When opened few were in the inhalent chamber but there were many in the exhalent chamber and filling the water tubes of each demibranch, and more were seen issuing from the genital pore. The eggs, which moasured $323 \times 264 \mu$, were exceptionally large for a lamellibranch with pelagic larvæ. Thorson ${ }^{5}$ noted that the largest lamellibranch egg to develop into a pelagic stage (Yoldia limatula) has a diameter of $150 \mu$; those species with larger eggs have a direct non-pelagic development. In $O$. edulis the egg is $150 \mu$ in diameter and in $O$. lurida $100 \mu$. A number of individuals of $O$. chilensis have been observed to spill either eggs or early embryos in the exhalent current, and it is suggested that this is caused by the difficulty of forcing these very large eggs through the gills into the inhalent chamber.

Some of the adults which had spilled eggs or early. embryos over a period of 3 days were separated from nonbreeding individuals. When one was opened 11-13 days later the larva had grown to a mean shell length of $331 \mu$ at a temperature of $13^{\circ}-15^{\circ} \mathrm{C}$. When another was opened after 27-29 days the larvæ had a mean shell length of $390 \mu$; the temperature in the second part of the period had been $9^{\circ}-14^{\circ} \mathrm{C}$. A sample of this brood was cultured and at $13^{\circ}-14^{\circ} \mathrm{C}$ the shell length of the larvæ grew at about $10 \mu$ per day. A rudimentary foot was seen on the third day and on the seventh day the foot was well developed, a row of rudimentary gill filaments was visible and the eye spot was clearly developing. On the eleventh day one spat was found attached to the wall of the vessel and many on the fourteenth day. It is probable then that the incubation period at temperatures of $13^{\circ}-15^{\circ} \mathrm{C}$ is about $5-6$ weeks.

The spat have grown well after settlement and some exceeded $1 \mathrm{~mm}$ in length within 12 days at $13^{\circ}-15^{\circ} \mathrm{C}$. The very short free-swimming larval life suggests that $O$. chilensis might be a valuable species to introduce into British waters, since the loss of larvæ by tidal currents and predators would be substantially reduced and most of the settlement would take place near to the parent stock. The temporature at which breeding occurs is lower than the $17^{\circ}-20^{\circ} \mathrm{C}$ required by $O$. edulis, and this could result in an earlier production of spat and, since the larve at release are more mature than those of $O$. edulis, spatfall would presumably be more reliable. There is the possibility, however, that production of larva would continue for a large part of the year, resulting in thin oysters with a proportion 'white sick' during the normal marketing season. In this case $O$. chilensis might be suitable only for the cooler waters of the British Isles. In external appearance it closely resembles $O$. edulis and in the imported sample the oysters wore in excellent condition.

${ }^{1}$ Soot-Ryen, T., Acta Cniv, Lund Avd. (2) 55, No. 6 (1959).

2 Hollis, P. and Millar, R. H., Nature, 197, 512 (1963).

s Brattström. H. and Dahl, E., Acta Tniv. Lund Avd. (2) 46, No, 8 (1951).

* Ranson, (t., Bull. Inst., océanogr. Monaco, No. 1183 (1960).

"Thorson, $(\mathrm{H}$, Medd. Gronland, 100, No. 6 (1936). 